遠位型腎尿細管性アシドーシスに伴ら尿路結石症に対する

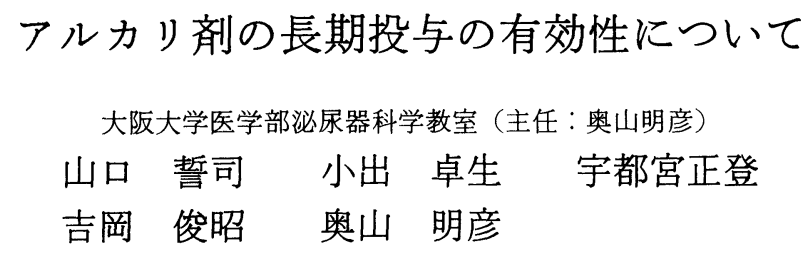

\title{
THE EFFECT OF LONG TERM ALKALI THERAPY FOR RECURRENT CALCIUM STONE PATIENTS WITH DISTAL RENAL TUBULAR ACIDOSIS
}

Seiji Yamaguchi, Takuo Koide, Masato Utsunomiya, Toshiaki Yoshioka and Akihiko Okuyama

Department of Urology, Osaka University School of Medicine

(Professor: Akihiko Okuyama)

Alkali therapy is widely accepted as a treatment for recurrent calcium stone patients with distal renal tubular acidosis (dRTA).

Nine patients, five with complete and four with incomplete type of dRTA, were treated with alkali agents for more than three years; an average period of 10.8 years. In five patients, new stone formation and stone growth were completely prevented by this treatment. Among the four failed cases, three did not take enough alkali agents (in spite of our medication), and the other had recurrent urinary tract infection resulting in infectious stone formation.

In conclusion, the long-term efficacy of alkali therapy for prevention of recurrent stone formation with dRTA is confirmed when the patient takes enough alkali agents and the urinary tract infection is well controlled.

Key words: distal renal tubular acidosis, calcium renal stone, alkali therapy

\footnotetext{
要旨：遠位型腎尿細管性アシドーシス (dRTA)に伴ら尿路結石症に対する治療としてはアルカリ剤が一 般的によく使われているが，我々は長期アルカリ剂投与による結石再発予防効果について検討したので 報告する. 対象は大阪大学泌尿器科で経過観察中の dRTAに伴ら尿路結石症患者のらちアルカリ剤投与 を開始してから 3 年以上経過している症例を対象とした。対象症例は 9 例で完全型 5 例，不完全型 4 例 であり, 評価は治療前後の腹部レントゲン検査により, 結石増大の有無, 結石形成の有無について検討 した. 9 例中 5 例に結石の増大や，形成を認めず有効であったが，アルカリ剂が無効であった 4 例のう ち 3 例は服薬が不規則な症例であり，残りの 1 例は尿路感染の繰り返しにより，感染結石の形成を来た した症例であった。

dRTA に対するアルカリ剂の投与は尿中クエン酸排泄量の増加, 尿中カルシウム排泄量の低下等によ り有効であるとの理論的背景は明確にされているが臨床上も dRTA に伴う既存尿路結石の増大予防や 新たな結石形成を長期にわたり予防しうることが証明された。

キーワード：遠位型腎尿細管性アシドーシス，尿路結石症，アルカリ剂
}

\section{緒 言}

腎尿細管性アシドーシス(以下 RTA と略す)は腎尿 細管の異常による酸塩基平衡障害を呈する疾患で, 近 位尿細管での $\mathrm{HCO}_{3}^{-}$の再吸収障害である近位型尿細 管性アシドーシス（pRTA）と遠位尿細管での $\mathrm{H}^{+}$の排
泄障害である遠位型尿細管性アシドーシス $(\mathrm{dRTA}) に$ 大別される。このうち遠位型尿細管性フシドーシスは 高率に腎結石症や腎石灰化症を合併し，この疾患を早 期に確実に診断し，治療を行うことが腎の実質障害を 予防しうる唯一の方法とされている12) . dRTA 患者に 
伴う腎結石症や腎石灰化症に対するアルカリ療法の短 期的な効果についてはすでに周知のところである が3(4)，その長期的な効果についての報告は少ない，今 回我々は長期アルカリ剤投与による結石再発予防効果 について検討したので報告する.

\section{対象と方法}

大阪大学泌尿器科を受診した腎尿細管性アシドーシ スに伴う尿路結石患者21例のらちでフルカリ剤の投与 を開始してから 3 年以上経過している症例を対象とし た．RTAの診断は Wrong らの方法 ${ }^{51} に よ り$ 経口塩化 アンモニウム負荷試験 $(0.1 \mathrm{~g} / \mathrm{kg}) 8$ 時間法を行い，尿 $\mathrm{pH}$ が5.3以下にならないものを RTA とし，動脈血が ス分析にて明らかなアシドーシスの存在するものは完 全型と診断し，明らかなアシドーシスが認められなく ても，経口塩化フンモニウム負荷試験に打いて，尿の 酸性化障害が認められるものは不完全型と診断した。 対象症例は完全型 5 例，不完全型 4 例の 9 例で，初診 時の年齢は22歳から50歳で平均 35.6 歳であった。男性 は 4 例，女性は 5 例であった。治療期間は 4 年から 14 年で平均 10.8 年であった。

治療薬剤は現在全例クエン酸カリウムとクエン酸ナ

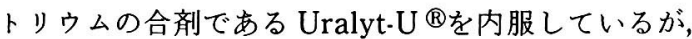
Uralyt-U ${ }^{\circledR}$ 発売以前初期の頃は変法ショール氏液を 使用し，次いで Uralyt-U ${ }^{\circledR}$ と同一成分のものを院内で
処方し内服させていた. 分量は Uralyt-U ${ }^{\circledR}$ とて完全 型は6 9g/日，不完全型は3 6g/日内服している。

アルカリ剂投与前と投与を開始してから最も最近の 腹部レントゲン検查により結石増大の有無，結石形成 の有無について検討した。評価は結石の増大や新たな 結石の形成を認めないものを有効とし，結石の増大や 新たな結石の形成を認めたものを無効とした。また腹 部レントゲン検査にて確認できなくても結石の自排を 繰り返すものも無効とした。

\section{結 果}

全症例は表 1 に示した通りであった。

結果はレントゲン上結石の増大を認めなかったもの は完全型 4 例, 不完全型 1 例で有効例は 5 例であった。 また，結石の増大を認めたもの3 例，レントゲン上結

\section{表 1 症例}

\begin{tabular}{|c|c|c|c|c|c|c|c|}
\hline No & 症例 & 年粭 & 性 & タイブ & 現在の治療 & 治瘖期間 & 経過 \\
\hline 1 & Y.S. & 22 & $M$ & 不完全型 & 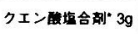 & 14年 & 增大 \\
\hline 2 & E.T. & 28 & $F$ & 不完全型 & 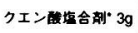 & 14年 & 変化なし \\
\hline 3 & H.K. & 39 & $F$ & 完全型 & クエン酸堛合硳・9g & 14年 & 增大 \\
\hline 4 & T.S. & 50 & $M$ & 不完全型 & 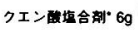 & 14年 & 結石の自津度 ん \\
\hline 5 & K.T. & 38 & $F$ & 不完全型 & 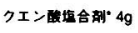 & 13年 & 增大 \\
\hline 6 & T.K. & 31 & $M$ & 完全型 & 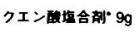 & 10年 & 変化なし \\
\hline 7 & S.M. & 35 & $M$ & 完全型 & クエン磷塔合剧・9g & 10年 & 変化なし \\
\hline 8 & Y.O. & 39 & $F$ & 完全型 & 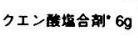 & 4年 & 変化なし \\
\hline 9 & F.T. & 38 & $\mathrm{~F}$ & 完全型 & クエン酸堛合威“9g & 4年 & 変化なし \\
\hline
\end{tabular}

図 1 フルカリ療法が有効であった症例
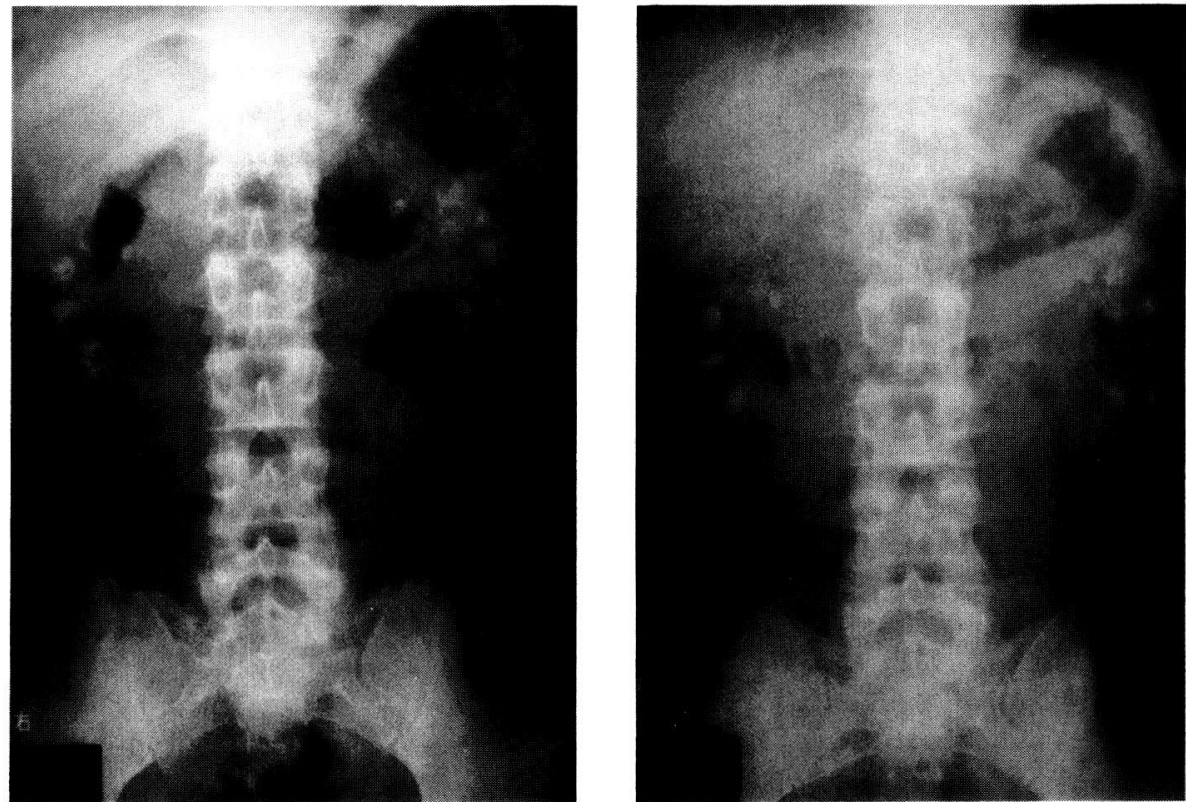


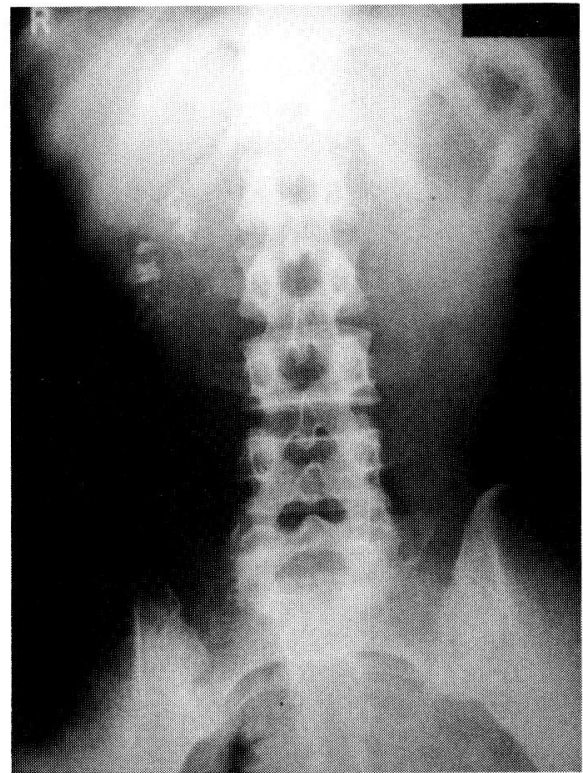

石陰影を認めないものの結石の自排を繰り返すもの 1 例であり，無効例は 4 例であった。

無効例のうちで完全型の 1 例と不完全型の 2 例は服 薬が不規則な症例であり，残りの不完全型の 1 例は繰 り返す尿路感染のために感染結石の形成を来たした症 例であった。

アルカリ療法が有効であった症例の腹部レントゲン 検查を図 1 亿示した。 これ症例No.6の完全型の症 例で左が投与開始前，右が投与開始してから10年後の レントゲンであり, 両側の多発性の結石陰影は変化が ほとんど認められなかった。

図 2 は症例 No. 5 の不完全型の症例で左が投与前, 右が投与開始してから13年後の腹部レントゲン検査で あるが，右腎内の多発結石陰影の若干の増大凝集傾向 を示して扮り，左腎に新たな結石形成を来たしている。 これは繰り返す尿路感染のためにカルボネートアパタ イト結石の形成を来たした症例であった，尿路感染時 の起炎菌は主にE. coli で, 尿 $\mathrm{pH}$ は $\mathrm{pH}$ 6.5 6.8の範 囲であり，治療は主にセフェム系抗生物質を使用しな がらアルカリ療法を行った。な掞この症例は最近，右 腎結石に対して ESWL 治療を行いstone free とし， アルカリ療法を継続している。

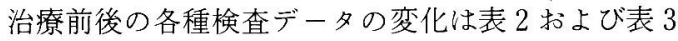
に示した。アシドーシスの補正により動脈血 $\mathrm{pH}$, $\mathrm{HCO}_{3}^{-}$の正常化，および尿 $\mathrm{pH}$ の上昇がみられた。血

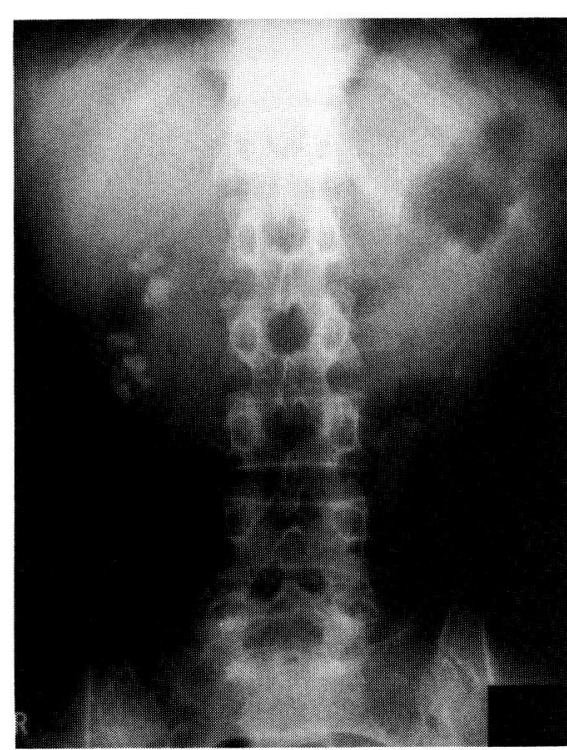

表 2 治療前後の尿および血液生化学的検査

\begin{tabular}{|c|c|c|c|c|c|c|c|c|c|}
\hline \multirow[t]{2}{*}{ No } & \multirow[t]{2}{*}{ 症例 } & \multicolumn{2}{|c|}{ 尿 $\mathrm{pH}$} & \multicolumn{2}{|c|}{ 血液 $\mathrm{pH}$} & \multicolumn{2}{|c|}{ 血液重炭酸イオン } & \multicolumn{2}{|c|}{$\mathrm{Cer}$} \\
\hline & & 前 & 後 & 前 & 後 & 前 & 後 & 前 & 後 \\
\hline 1 & Y.S. & 6.31 & 5.95 & 7.356 & 7.395 & 23.1 & 23.5 & 119 & 90.5 \\
\hline 2 & E.T. & 6.50 & 6.73 & 7.404 & 7.443 & 21.8 & 24.7 & 106 & 81 \\
\hline 3 & H.K. & 7.01 & 6.98 & 7.343 & 7.432 & 16.7 & 23.5 & . & - \\
\hline 4 & T.S. & 6.48 & 7.65 & 7.356 & 7.360 & 20.7 & 20.7 & 158 & 146 \\
\hline 5 & K.T. & 6.41 & 7.36 & 7.398 & 7.416 & 25.0 & 27.7 & 72 & 73.7 \\
\hline 6 & T.K. & 6.87 & 6.96 & 7.342 & 7.383 & 16.5 & 23.5 & 65 & 66.4 \\
\hline 7 & S.M. & 6.49 & 7.52 & 7.292 & 7.407 & 15.2 & 23.0 & 68 & 98.7 \\
\hline 8 & Y.O. & 6.49 & 7.00 & 7.353 & 7.426 & 19.2 & 23.0 & 99.3 & 128 \\
\hline 9 & F.T. & 6.62 & 7.06 & 7.337 & 7.411 & 13.8 & 21.8 & - & - \\
\hline
\end{tabular}

表 3 治療前後の血清電解質の変化

\begin{tabular}{lcc}
\hline & before & after \\
\hline s-Ca $(\mathrm{mg} / \mathrm{dl})$ & $9.73 \pm 0.64$ & $9.38 \pm 0.49$ \\
s-iP $(\mathrm{mg} / \mathrm{dl})$ & $3.46 \pm 0.56$ & $3.32 \pm 0.34$ \\
s- $\mathrm{Na}(\mathrm{mEq} / \mathrm{l})$ & $143.38 \pm 1.92$ & $143.11 \pm 2.26$ \\
$\mathrm{~s}-\mathrm{K}(\mathrm{mEq} / \mathrm{l})$ & $3.98 \pm 0.47$ & $4.42 \pm 0.42$ \\
$\mathrm{~s}-\mathrm{Cl}(\mathrm{mEq} / \mathrm{l})$ & $109.5 \pm 5.86$ & $106.67 \pm 4.47$ \\
\hline
\end{tabular}

Values are presented as mean \pm standard deviation

清カリウムは $3.97 \mathrm{mEq} / l$ から $4.4 \mathrm{mEq} / l$ と有意に上 昇し，クロールは有意差は認めないものの下降傾向を 示した。 なた血清リン，ナトリウムの值はアルカリ剤 投与前後で変化は見られず，また低カルウシム血症も 認めなかった。

尿中カルシウム排泄量は治療前と治療後では図 3 に 示すように有意に低下が認められる。これは他の報告 
図 3 治療前後の尿中カルシウム排泄量の変化

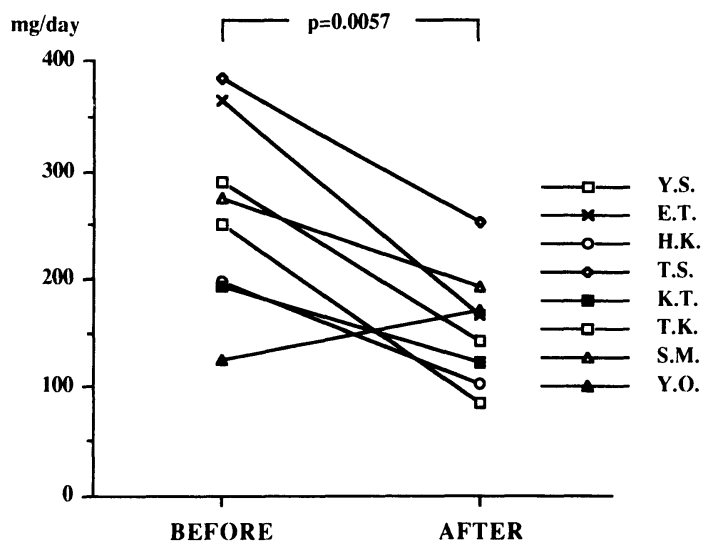

図 4 治療前後の尿中リン排泄量の変化

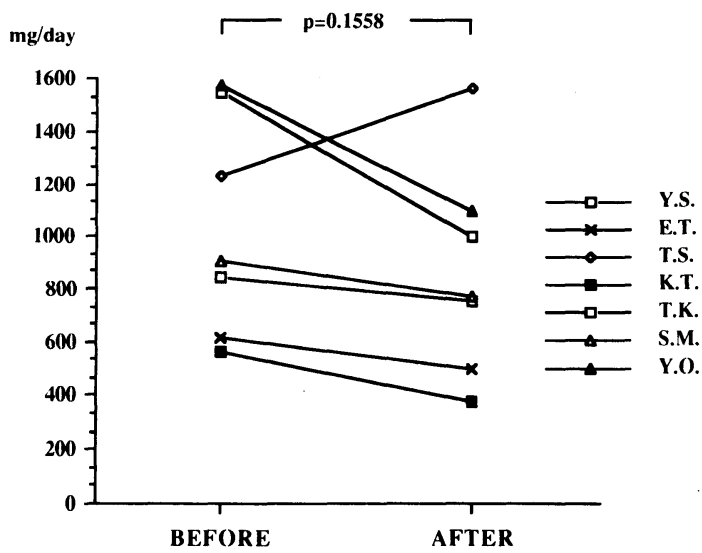

とも同様の結果であった。 また尿中リン排泄量も低下 傾向になっていたが，有意差は認めなかった（図 4 ）. なお，治療前後に颃いて腎機能の有意な差を認めな かった。

\section{考察}

再発性尿路結石症患者中を占める dRTAの頻度は

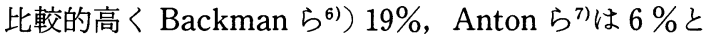
報告している.また我々の施設では750人の尿路結石症 患者中に占める dRTA の割合は $1.9 \%$ であり, 380 人の 再発性尿路結石症患者中に占める RTA の割合は3\% となっており，その頻度もさることながら，再発性尿 路結石症の原因としては薬物治療によりほぼ完全に再 発予防がなし得るといった観点からも重要な疾患の 1 つである ${ }^{8)}$ また, dRTA 患者中に占める腎結石症の割 合は $56 \%$ とも，77\%とも言われている ${ }^{1)}$. 高率に腎石灰 化症も合併するとの報告もある.
dRTA 患者における腎結石症，腎石灰化症の機序と してはKonnak ら゙)

1）尿中カルシウム排泄量の増加.

2）カルシウムと結合し, 溶解性の高いカルシウムと の錯塩を作るクェン酸排泄量の低下.

3）尿 $\mathrm{pH}$ の上昇のためにリン酸塩の溶解度が低下 すること，等を指摘しているがいずれにせよ複数の結 石形成の危険因子の存在が挙げられる。

高カルシウム疗症の発生の機序としては現在いくつ かの可能性が考えられており，単一のメカニズムで全 ての症例を説明しがたい。

まず，第一番目としてアシドーシスが直接尿細管に 作用し，カルシウム再吸収を抑制するという考え方が ある。

Lemann ら ${ }^{9}$ は正常人に $\mathrm{NH}_{4} \mathrm{Cl}$ を投与すると代謝 性アシドーシスとともに尿中カルシウム排泄量の上昇 を認め，これらは副甲状腺機能低下度の 4 症例でも同 様に認められていることより PTH が関与することな くアシドーシスが直接尿細管に作用し，カルシウムの 再吸収を抑制すると報告している。

Coe $5^{8)}$ は尿中カルシウム排泄量の増加とともに PTHの上昇を認めて打り，これはアシドーシスに遅 れて起こることより，アシドーシスの直接作用ではな くて，高カルシウム尿症によるものと推定している. これは高カルシウム尿症により血清総カルシウムおよ びイオン化カルシウムの低下が起こり，そのため PTH 分泌が亢進していると考えている. 高 $\mathrm{Ca}$ 尿症そ のものは糸球体濾過量に比較してアシドーシスによる 再吸収量の低下によるものであるとしている，Higashihara $5^{11)}$ \& $\mathrm{PTH}$ の上昇は高カルシウム尿症によ る二次的なものと推定している.

二番目の考方としては，アシドーシス下では蛋白 結合カルシウム比率が低下しイオン化カルシウム比率 が上昇する。すなわちアシドーシスではイオン化カル シウム分画が増加し，アルカローシスでは逆に減少す る. 糸球体でのカルシウムの濾過は血漿中のイオン化 カルシウム分画と糸球体灌流血液量に依存するので, アシドーシスでは糸球体濾過カルシウムの量が多く, このためカルシウム排泄量が増加すると推定されてい る $^{12)}$. 従って, この場合血清イオン化カルシウムの上昇 により，PTH 分泌は抑制されている. 我々の以前の報 告でも治療前では血清イオン化カルシウムの上昇を認 め, PTH 分泌はむしろ抑制されて拉り，アルカリ剂投 与後, 血清イオン化カルシウムの明らかな低下と 
$\mathrm{PTH}$ の著明な上昇を認めた ${ }^{13)}$.

低クェン酸尿症は, Fourman と Robinson ら ${ }^{14)}$ によ り最初に報告されて初り RTA の結石形成の重要な因 子の一つであると考光られている，尿中のクェン酸排 泄は $\mathrm{pH}$ の変動に依存しており, クェン酸排泄量はア シドーシスでは減少し，アルカローシスで増加する。 尿細管に拈けるクエン酸の再吸収量は $\mathrm{pH} 5.5$ の時は $\mathrm{pH} 7.5$ の時に比べて約20倍も多いとされている ${ }^{15)}$.ク エン酸はカルシウムとのキレート結合により錯塩を形 成するがこの錯塩は溶解性が高いため, カルシウムが 苳酸やリン酸と結合し, 結晶を形成するのを防ぐ役割 を行っているとされている。このクェン酸の作用が， 結石形成の場に拈いてどの程度の影響を及ぼしている のかは不明であるが, 我々は今回尿中クェン酸排泄量 は一部の症例でのみ測定しており, 治療前後での測定 がなされている症例 E.T. では $324 \mathrm{mg} /$ day $\rightarrow 592 \mathrm{mg} /$ day と上昇して括り, 再発予防に関与していたことが 推定される。

尿 $\mathrm{pH}$ の上昇の関与についてはアルカリ尿ではリン 酸塩の溶解度が低下するからリン酸塩の結晶析出が方 進し, dRTA 患者の結石成分は一般にリン酸カルシウ ムである. dRTA 患者の場合尿は治療の如何にかかわ らずアルカリ尿が持続しており，リン酸カルシウム結 石の形成に関与していると推定されている。しかし今 回の検討では，尿の感染がなく規則的な内服を行って いる症例では尿 $\mathrm{pH}$ は治療前に比較しアルカリ剤の内 服中では有意に上昇していたにもかかわらず新たな結 石形成や既存の結石の増大を認めなかった，尿 $\mathrm{pH} の$ 上昇がリン酸カルシウム結晶の析出を加速し, リン酸 カルシウム結石形成を促進することが危惧されたが高 カルシウム尿症や低クェン酸尿症ほど重要な危険因子 ではないと考えられるに至った。

治療としてはアシドーシスの補正が最も重要かつ根 本的な治療であり，アシドーシスの補正により，高力 ルシゥム尿症, 低クエン酸尿症が補正される。このア ルカリ療法の有效性についてはよく知られるところで あるが，完全型のみならず不完全型に対してもアルカ リ療法にて高カルシウム尿症, 低クエン酸尿症の是正 が得られ, Konnak ら ら)の報告や Preminger ら ${ }^{4)}$ の報告 でも結石再発の予防に有効な成績が示されている. dRTAによる腎結石症や腎石灰化症に対するアル カリ療法は, 高カルシウム尿症の是正, 低クエン酸尿 症の改善により結石再発が予防されるとされておりそ の理論的背景はすでに確立されているが，一方でその
長期的な効果については現在のところまだ報告されて いない.我々は当初より dRTA 患者に対してアルカリ 療法を行ってきたが, 今回我々の長期的な経過観察の 結果, 高カルシウム尿症の改善を認めて抢り, 尿の感 染がない場合, 規則的なアルカリ剤投与によりきわめ て長期にわたり腎石灰化症, 腎結石の発生成長を予防 することができた。しかもその効果は完全型のみなら ず，不完全型の腎尿細管性アシドーシス患者に対して も, 結石再発予防に扮いてはアルカリ剤の投与が有効 であった。

しかしながら，アルカリ剤投与の際注意しなければ ならないのが尿路感染であり, 尿路感染を伴っていて もアルカリ剤の投与は必要である為, 抗生物質等によ り感染を取り除くことが重要である。ときには ESWL, Endourology 等により stone free とし, 感染 の原因を取り除くこともアルカリ化を行う上で必要で あると考兄れる。

\section{結 語}

dRTA に伴う尿路結石症に対し，アルカリ剂の長期 投与を行い以下の結果を得た。

1）アルカリ剂投与による結石再発予防効果につい ては，長期投与においてもその有効性が確認された。

2) 不完全型の dRTA 患者に打いても結石再発予防 にはアルカリ剤の投与が有効であった。

3）尿路感染を伴らときは結石の増大や形成に注意 しながら、アルカリ剂の投与を慎重に行らべきである。

本論文の要旨は第41回日本泌尿器科学会中部総会に括い て発表した。

\section{文献}

1) Caruana, R.J. and Buckalew, V.M. Jr.: The syndrome of dital (type 1) renal tubular acidosis. Clinical and laboratory findings in 58 cases. Medicne, 67, 84-99, 1988.

2) Buckalew, V.M. Jr.: Nephrolithiasis in renal tubular acidosis. J. Urol., 141, 731-737, 1989.

3) Konnak, J.W., Kogan, B.A. and Lau, K. : Renal calculi associated with incomplete distal renal tubular acidosis. J. Urol., 128, 900-902, 1982.

4) Preminger, G.M., Sakhaee, K., Skurla, C. and Pak, C.Y.C.: Prevention of recurrent calcium stone formation with potassium citrate therapy in patients with distal renal tubular acidosis. J. Urol., 134, 20-23, 1985.

5) Wrong, O. and Davies, H.E.F.: The excretion of acid in renal disease. Quart. J. Med., 28, 259-313, 1959. 
6) Backman, U., Danielson, B.G., Johansson, G., Ljunghall, S. and Wikstr, B.: Incidence and clinical importance of renal tubular defect in recurrent renal stone formers. Nephron, 25, 96-101, 1980.

7) Anton, F.M., Puig, J.G., Gaspar, G., Martinez, M.E., Ramos, T. and Pineiro, J.A.M.: Renal tubular acidosis in recurrent renal stone formers. Eur. Urol., 10, 55-59, 1984.

8) Koide, T., Oka, T., Takaha, M. and Sonoda, T.: Urinary tract stone disease in modern Japan, Stone incidence, Composition and Possible Causes in Osaka District. Eur. Urol., 12, 403-407, 1986.

9) Lemann, J. Jr., Litzow, J.R. and Lennon, E.J. : Studies of the mechanism by which chronic metabolic acidosis augments urinary calcium excretion in man. J. Clin. Invest., 46, 1318-1328, 1967.

10) Coe, F. and Firpo, J.J.: Effect of acute and chronic metabolic acidosis on serum immunor- eactive parathroid hormone in man. Kidney Int. 8, 262-273, 1975.

11) Higashihara, E., Nutahara, K., Takeuchi, T., Shoji, N., Araie, M. and Aso, Y.: Calcium metabolism in acidotic patient induced by carbonic anhydrase inhibitors: Responses to citrate. J. Urol., 145, 942-948, 1991.

12）藤田拓男：尿細管性アシドーシスに見られる代謝 異常, カルシウム, 燐代謝異常. 日本臨床, 43, 919-1924, 1985.

13）小出卓生, 武本征人, 板谷宏柣, 木下勝博: 腎尿細 管性アシドーシス, 特に血清カルシウムの動態に ついての一考察. 日泌尿会誌, 67, 99-102，1976。

14) Fourman, P. and Robinson, J.R.: Diminished urinary excretion of citrate during deficiencies of potassium in man: Prelimianry communication. Lancet, 2, 656-657, 1953.

15）郡健二郎, 井口正典, 加藤良成：尿路結石症におけ るクエン酸代謝, 腎と透析, 臨時增刊号, 338-342, 1987.

（1992年10月20日受理） 